
ВПРОВАДЖЕННЯ ДІАЛОГОВОЇ МОДЕЛІ В ОСВІТНІЙ ПРОЦЕС
ЗАКЛАДІВ ВИЩОЇ ОСВІТИ: ВИКЛИКИ ТА ПЕРСПЕКТИВИ

\title{
INTRODUCTION OF THE DIALOGUE MODEL IN THE EDUCATIONAL PROCESS OF HIGHER EDUCATION INSTITUTIONS: CHALLENGES AND PROSPECTS
}

Діалог - необхідна складова частина організованого навчання: по-перше, як основа розвитку творчого мислення та критичного ставлення до себе й довкілля, показник загальної культури особистості, а по-друге, потужний інструмент освітнього впливу на неї. Зазначено, що нині освітні заклади всіх рівнів, у тому числі й заклади вищої освіти, мають не лише подбати про забезпечення здобувачів освіти певним обсягом інфрормації, а й навчити їх основних прийомів самостійної пошукової активності, коли остання проходить складний процес осмислення та стає справжнім особистісним надбанням. Указується, що все че можливе лише за умов впровадження в освітній процес закладів вищої освіти діалогової моделі, основою якої мають стати партнерські паритетні відносини між студентами й викладачами, коли останній формує не лише систему знань, але й передає наступникам своє мотиваційно-ціннісне ставлення до них. Уточнено, що налагодження останніх ефективніше за допомогою ведення проблемного діалогу як особливого інструменту інноваційної освітньо діяльності. У статті наведені результати дослідження, метою якого стало визначення готовності учасників освітнього процесу до змін, що супроводжують впровадження діалогової моделі в освітній прочес закладів вищої освіти. Проаналізовано динаміку вимог до викладача студентів, які навчаються на різних курсах університету. Виявлено, що для здобувачів освіти на всіх етапах освітнього процесу важливі як особистісні, так і професійні якості наставників, але серед останніх все більшого значення надається їх здобуткам у практичній діяльності за тим фрахом, в якому вони здійснюють підготовку студентів. Доведено, що ефрективність впровадження діалогової моделі в освітній процес закладів вищої освіти залежить від цілої низки чинників, а саме: прийняття викладачем новаторської позиції у відносинах зі студентами, готовності самих студентів до інноваційних змін, які із чим пов'язані, і врахування реальних освітніх запитів, потреб та інтересів здобувачів освіти.
Ключові слова: діалогова модель, паритетна взаємодія, заклад вищої освіти, освітній процес, проблемний діалог, інноваційна діяльність.

Dialogue represents a necessary component of organized learning, in the first place, as a basis for the enhancement of creative thinking and critical attitude to themselves and the environment. It is an indicator of the general culture for the individual, and secondly is an effective tool for educational influence on it. It notes that today educational institutions of all levels, including HEl, should take care not only to provide students with a certain amount of information. Moreover, to demonstrate to students the fundamental techniques of independent search activity during a complex reflection process and becomes a substantial personal asset. It indicates that all this is possible under the conditions of the dialogue model introduction in the HEI educational process based on partnership parity relations among students and teachers. When the teachers form not only a knowledge system but also pass to successors its motivation and valuable attitude to them. It is specified that the latter can be established only through problem dialogue as a significant tool for innovative educational activities. The article presents the study results aiming to determine the participant readiness to the changes followed by the dialogue model introduction in the educational process of $\mathrm{HEl}$. The dynamics of the requirements for the teacher of students studying at various university courses are analyzed. It identifies that both personal and professional qualities of mentors are significant for students at all stages of the educational process, more and more importance is given to their achievements in practical activities in the specialty in which they prepare students. It proves the effectiveness of the dialogue model introduction in the educational process of $\mathrm{HEI}$ depends on several factors: namely the adoption of an innovative position by the teacher in relation with students, readiness of students themselves for innovative changes related to this, and considering the real educational needs, needs and interests of students.

Key words: dialogue model, parity interaction, $\mathrm{HEl}$, educational process, problem dialogue, innovative activity.
Сучасний етап розвитку суспільства вимагає підготовки креативних і вмілих фахівців, спроможних, з одного боку, відповідати всім вимогам конкурентного середовища, а з іншого, - рухатися власною траєкторією особистої та професійної самореалізації. Нині це питання особливо гостро постає перед різноманітними освітніми інституціями, пріоритетним напрямом якихє підготовка освіченого, висококваліфікованого, вмотивованого, відповідального й конкурентоздатного фахівця, спроможного самостійно приймати рішення в ситуації вибору, готового до співпраці, який не лише вільно володіє своєю професією, але й зорієнтований на суміжні сфери діяльності.

Отже, нагальною та актуальною стає переорієнтація всієї освітньої системи на нову діалогову модель, основою якої мають стати нові цінності, що детермінують рівноправні, паритетні й плідні взаємини між викладачем і студентами.

Діалогова модель взаємодії насправді має давні традиції та бере свій початок ще із часів античної філософії, яка найяскравіше втілена в працях Сократа й продовжена в роботах його послідовників. Психолого- 
педагогічна наука також має досить напрацювань у такому напрямі й нині набула статусу міждисциплінарної, оскільки інтегрує наукові дослідження в царинах соціології, педагогіки, методології, соціальної та педагогічної психології та інших. Зокрема, вітчизняні й зарубіжні науковці досліджували взаємодію як форму суб'єкт-суб'єктних взаємин (Б.Ф. Ломов, O.M. Матюшкін, Е. Фромм, Г.А. Цукерман та інші), проблеми взаєморозуміння та діалогічної взаємодії (Г.О. Балл, А. Маслоу, Р. Мей, К. Роджерс, В.А. Семиченко й інші), структуру й технології педагогічної та освітньої взаємодії (А.М. Алексюк, О.В. Киричук, А.В. Фурман та ін.), підготовку майбутніх фахівців до професійної взаємодії (І.С. Булах, Г.С. Костюк, В.О. Сластьонін та інші), підготовку викладача до педагогічної взаємодії (В.Я. Ляудіс, О.В. Матвієнко, О.Є. Фурман та інші).

Таким чином, нині в психолого-педагогічній науці затверджується концепція особистісно зорієнтованої освіти, в якій діалогова модель взаємодії між учасниками освітнього процесу все більш наполегливо витісняє авторитарну, акцентуючи на суб'єктних відносинах між викладачем і студентом, розумінні й оволодінні технологією партнерства й паритету.

Незважаючи на змістовність і глибину наявних досліджень такої проблематики серед сучасних науковців, котрі, зокрема, зосереджують свій погляд на проблемах розбудови вищої школи, і досі є досить багато розбіжностей, що стосуються насамперед самого феномену діалогічності, його технологічних аспектів, специфіки становлення, умов і факторів налагодження партнерських відносин.

Таким чином, актуальність нашого дослідження визначається протиріччям між об'єктивними потребами практики, яка прагне модернізувати освітній процес у закладах вищої освіти (далі - ЗВО) на основі діалогічної взаємодії, партнерства як співтворчості викладача й студента, і недостатньою розробленістю теорії шляхів, способів технології розв'язання складної проблеми паритетної взаємодії його учасників, а найголовніше - готовності учасників освітнього процесу до інноваційної діяльності, яка вимагає від них докладання значних зусиль, вмотивованості, боротьби зі стереотипами й усвідомленого ставлення.

Зазвичай проблему пошуку оптимальної моделі освітньої взаємодії пов'язують із новими завданнями вищої школи, які змінюються відповідно до нагальних вимог до особистісних і професійних якостей особистості, її поведінки, складу мислення тощо, і насамперед розпочинають із пошуку оптимальних форм, методів, технологій навчання. Усе це становить підґрунтя так званої інноваційної освітньої діяльності, провідною метою якої є зміна традиційних компонентів репродуктивних видів взаємостосунків між учасниками освітнього процесу $3 В 0$ на нові паритетні й партнерські. Але не менш важливим за такої умови є дослідження готовності останніх до таких змін.

Дослідники інноваційних процесів у системі «викладач - студент» зауважують, що проблема готовності як викладача, так і студента до інноваційної діяльності досить складнай різноаспектна й значним чином пов' язана з мотиваційно-цільовою спрямованістю (прагненням до творчих досягнень, самовдосконаленням) і креативністю особистості [8]. Передбачається, що особистість, яка зважилася на зміни, відкрита до різноманітних суспільних і культурних проявів, толерантна, а також готова як до зовнішніх, так і до внутрішніх трансформацій. А для цього їй необхідно позбутися хибних стереотипів та установок, трансформувати позиції та усвідомити й прийняти нові ролі й функції. Йдеться насамперед про викладачів. З одного боку, це продиктовано об'єктивними чинниками, адже більшість із них самі навчалися та розпочинали свій професійний шлях ще за умов традиційного підходу до побудови освітнього процесу, в якому позиція вчителя чи викладача завжди була пріоритетною щодо учня чи студента. Роки, а інколи й десятиліття перебування в такій системі так чи інакше відбилися на особистісних переконаннях і визначили ціннісні орієнтири. Інноваційні ж процеси й зміни змушують кардинально трансформувати останні, а це не завжди вдається. 3 іншого боку, не менше важливим є соціально-психологічні детермінанти становлення та розвитку викладача - особистий досвід, культура, професійні можливості й прагнення, а найголовніше - бажання змінювати й приймати ті зміни, які відбуваються навколо [1-5; 8; 9].

Сучасний рівень вимог до викладача надзвичайно високий. Він передбачає не лише наявність у нього загальних особистісних і фахових компетентностей (володіння достатнім рівнем знань навчальних дисциплін, які викладаються, і вміння їх доносити до студентів з урахуванням їх особистісних та індивідуально-психологічних особливостей, достатнє володіння технологіями, методами, засобами побудови освітнього процесу тощо), а й наявність додаткових знань та умінь (психологічна грамотність, методологічна культура, досвід створення та впровадження смислотворчих авторських освітніх програм, розуміння змісту самостійної діяльності студентів і вміння її організовувати, рефлексія тощо). Як зауважують деякі дослідники [12], саме остання - один із найважливіших показників рівня професіоналізму викладача, адже передбачає не лише самовизначення до морально-духовної сторони події, вчинку інших людей або власного, а й уміння стимулювати її в студентах - вчити 
здійснювати вчинки, оцінювати їх і критично до них ставитися, шукати різноманітні варіанти виходу зі складних життєвих ситуацій і вміти приймати поразки тощо. Така робота допомагає спочатку налагодити внутрішній діалог, який пізніше стане основою діалогічного процесу між учасниками освітнього процесу [10].

Іншим, не менш важливим аспектом ефективного впровадження в освітній процес ЗВО діалогічної моделі взаємодії між його учасниками $є$ готовність до цього самих студентів. Інноваційне навчання в сучасному закладі вищої освіти передбачає пріоритетність самостійної діяльності студента, а отже, зміну форм і методів взаємодії з викладачем. Він має можливість сам визначати траєкторію свого особистісного й професійного розвитку, рухатися з комфортною для нього швидкістю та сам обирати пріоритети. Викладач лише допомагає, створюючи умови для досягнення проставленої мети. А для цього сам студент має демонструвати високий рівень мотивації до навчання, максимальне залучення інтелектуальних, емоційних і вольових сфер власної психіки, мобілізацію всіх соціальних, комунікативних резервів організації та самоорганізації. А до такого готові також не всі молоді люди.

Отже, висновуємо, що процес побудови й становлення партнерських, паритетних відносин - складна й тривала процедура, в організації якої мають бути зацікавлені й до якого мають бути залучені й викладачі, і студенти, котрі зможуть перебудувати сам зміст внутрішньої системи відносин із традиційних стереотипізованих на особистісно розвиваючі. Та, як показують результати останніх наукових досліджень і спостережень, на практиці нині все ще залишається досить багато традиціоналізму й стереотипів щодо впровадження інноваційних відносин у практику організації освітнього процесу ЗВО. Так, як свідчать останні дослідження, близько 80\% інноваційної діяльності педагогів зводиться насамперед до поглиблення та розширення змісту освіти й тільки 10\% - до розробки й реалізації психозберігаючих технологій навчання, які передбачають створення комунікативно-горизонтального середовища як освітнього простору на єдиних демократичних засадах, що окреслює відносини партнерства на основі діалогічної паритетної взаємодії головних учасників [8].

Прагнення та готовність до змін усіх учасників освітнього процесу нині не єдина проблема впровадження діалогової моделі в практику вищої школи. На нашу думку, більш фундаментальним $є$ розрив між теорією та практикою інновацій. Йдеться про те, що будь-який заклад вищої освіти - живий організм, який, з одного боку, живе за законами системи, а з іншого, - має свої традиції, особливості й пріоритети. Змінити його повністю та кардинально одразу неможливо, адже це може мати непередбачувані наслідки. Тому важливо знайти такі варіанти, які б, з одного боку, зберігали основу освітнього процесу, а з іншого, - давали можливість поступово й наполегливо впроваджувати різні форми інноваційних змін та отримувати результат. Яскравим прикладом такої кооперації може слугувати авторська освітня модель підготовки фахівців соціогуманітарної сфери, яка вже друге десятиліття успішно втілюється в практику діяльності кафедри психології та соціальної роботи Західноукраїнського національного університету [12-13]. Вона, з одного боку, не заперечує традиційну модель, не ламає її, але з іншого, - за допомогою спеціального технологічного й програмово-методичного інструментарію дає можливість створення ціннісно-комунікативного поля взаємодії на навчальних заняттях профільних дисциплін, сприяє формуванню в майбутніх фахівців тих якостей, які складають ядро партнерства: активну творчу позицію, комфортність у стосунках, здатність до участі в діалозі, до спільних дій, автономності, відповідальності. Провідний принцип комунікативної спрямованості реалізується за допомогою використання основного інструменту взаємодії - проблемного діалогу, що є стратегічним на таких заняттях, дає змогу сконструювати систему засобів на основі діалогових технологій, яка роками апробовується на кафедрі [див. 6-7].

Для з'ясування деяких аспектів досліджуваної проблематики нами було проведене анкетування серед учасників освітнього процесу Західноукраїнського національного університету (Тернопіль, Західноукраїнський національний університет, квітень 2021, вибірка 150 студентів, 25 викладачів). Зокрема, було поставлене питання про те, якій моделі взаємовідносин «викладач - студент» Ви надаєте перевагу? У результаті були отримані такі дані: 72\% студентів віддали перевагу комунікативно-горизонтальній взаємодії, 18\% - вертикальній ієрархії, 7\% - вертикально-горизонтальній взаємодії та 3\% не змогли визначити свій вибір. Щодо викладачів, то $68 \%$ із них визнають важливість паритетних взаємовідносин і готові до них, 19\% - хочуть зберегти деяку перевагу й обрали вертикально-горизонтальну модель взаємодії, а 13\% - все ще переконані, що вертикальна модель найбільш дієва.

Але основною метою нашого дослідження стало вивчення динаміки вимог до викладача студентів, які навчаються на різних курсах. Отже, аналіз отриманих даних показав, що на молодших курсах надається перевага моделі «доброго», «розуміючого» викладача, для якого найважливішими якостями є комунікативні здібності, толерантність, емпатія та співчуття. 
Починаючи з третього курсу, пріоритетом стає професійна компетентність, коли студентами особливо цінуються особистісні й фахові якості наставника, який не лише знає та вміє донести наукову інформацію до аудиторії, а й зміг зреалізувати себе ще й у практичній діяльності й досяг там певних успіхів. Зауважимо, що така думка повністю збігається 3 концепцією практико-зорієнтованого навчання, яка нині є пріоритетом більшості ЗВО, що впроваджують засади інноваційного навчання. Відповідно до її засадничих положень частину навчального навантаження мають займати заняття практичного спрямування, які проводяться фахівцями, котрі працюють у різних галузях, передбачених освітніми програмами конкретної спеціальності. Це можуть бути як запрошені спеціалісти, так і викладачі ЗВО, які мають певний досвід роботи за визначеним напрямом підготовки.

Ближче до закінчення навчання, а саме для четвертокурсників бакалаврату й магістрантів особливо цінними стає поєднання й особистісних, і професійних якостей викладача захопленість предметом викладання та знання його, інтерес до особистості студента, повага, терпимість, розуміння, доброзичливість, справедливість тощо, що можна пояснити зростанням потреби в особистих контактах із викладачем. Водночас для більшості студентів усіх курсів абсолютно неприйнятними $€$ низький рівень особистісної та професійної культури, непрофесіоналізм, нетерпимість, фальш, приниження гідності студента, зарозумілість, жорстокість, злість, агресивність.

Зважаючи на ту обставину, що більшість здобувачів освіти хочуть позитивних трансформацій у відносинах із викладачами й розуміють, якими вони мають бути, чи готові вони самі змінюватися та працювати над собою стало наступною метою нашого дослідження. У результаті були отримані такі дані - 73\% студентів позитивно ставляться до змін у студентському житті, 17\% - негативно, 10\% - не впевнені у свій позиції. Водночас понад половина опитаної молоді (54\%) впевнені, що вони впораються з усіма труднощами, які неминуче несуть із собою ці зміни; 32\% заявляють про готовність їх вирішувати; 9\% впевнені, що зможуть їх вирішити, і тільки 5\% переконані, що не зможуть із цим впоратися.

Отримані дані є досить оптимістичними, але вимагають й ретельного аналізу. На нашу думку, такий результат пов'язаний насамперед із соціально-психологічними характеристиками покоління, до якого належить сучасне студентство. Серед них - прагнення до самостійності, впевненість у власних силах, інколи надмірна самовпевненість тощо. Практика реального повсякдення вказує на те, що, коли йдеться про необхідність поєднання цих яко- стей із власним високим рівнем відповідальності, наполегливості, активності й вмотивованості, більшість студентів не завжди готові до таких кроків.

Щодо викладачів, то більшість із них (65\%) визнають необхідність змін. Але все ж значна частина (25\%) вагається чи (10\%) зовсім їх не хоче. На нашу думку, це пов'язано насамперед із тим, що вони усвідомлюють всю відповідальність за результати впровадження будьяких інновацій і знають про реальні труднощі, які супроводжують цей процес. Адже такі трансформації мають змінити не лише сам формат відносин між учасниками освітнього процесу, а й бути підкріпленими ще й відповідними оргтехнологічними й організаційними перетвореннями, новими формами, методами й інструментами, які забезпечать успішність впровадження всієї діалогічної моделі.

Отже, основне завдання викладача, який готовий до впровадження в освітній процес ЗВО інноваційної діалогічної моделі - підтримати прагнення та готовність студентів до змін і на основі максималізму молодості сприяти розвитку й становленню лише тих важливих ділових якостей, які, безсумнівно, допоможуть майбутнім фахівцям адаптуватися до навколишнього середовища й бути готовими до конкуренції на сучасному ринку праці.

Ще один надзвичайно важливий фактор, який вимагає побудови партнерської лінії взаємодії, - це реальні потреби, освітні запити й інтереси студентів. Не секрет, що нині ставлення студентів до сучасної системи освіти стає все більш прагматичним, прискіпливим і вимогливим. Здобувач освіти чітко налаштований на отримання актуальної системи знань, умінь і навичок, які, на його думку, будуть точно корисні для нього в реальному житті й допоможуть в особистісній і професійній самореалізації. Сучасний студент не погоджується з орієнтацією на "середньостатистичну одиницю", він хоче особистісно зорієнтованого підходу й вимагає створення максимально комфортних умов для свого розвитку. I це продукує нову суперечність - вимогливість із боку студента до видів, форм, методів навчання, переліку дисциплін навчального плану, можливість їх вибору, а реалізація принципу дуальної освіти має повністю змінити і його ставлення до самого навчання - 3 позиції стороннього споживача освітніх послуг він має стати свідомим їх співавтором. А це знову ж таки можливо лише за умов налагодження паритетної партнерської взаємодії всіх учасників освітнього процесу.

Отже, висновуємо, що ефективність впровадження діалогічної моделі в освітній процес ЗВО залежить від цілої низки чинників, а саме від прийняття викладачем новаторської позиції у відносинах зі студентами; готовності 
самих студентів до інноваційних змін, які із цим пов'язані, і урахування реальних освітніх запитів, потреб та інтересів здобувачів освіти.

Підготовка фахівців, котрі готові до розв'язування складних життєвих і професійних задач - пріоритет сьогодення. Це стає можливим лише за умов побудови освітнього середовища іншого рівня, за умов відмови від відносин патерналізму у вищій школі й встановлення паритетності й партнерства між викладачем і студентами. Водночас системоутворюючим чинником має стати діалогічна взаємодія, яка змінює формат відносин, має проблемний характер, що змушує здобувачів освіти не просто отримувати знання, а робити їх справді важливими, усвідомленими й цінними для себе.

\section{ЛІТЕРАТУРА:}

1. Биков В.Ю. Теоретико-методологічні засади моделювання навчального середовища сучасних педагогічних систем. Інформаційні технології і засоби навчання : збірник наукових праць. Київ : Ін-т засобів навчання АПН України ; Атіка, 2005. С. 5-15.

2. Булах I.C. Психологічні аспекти міжособистісної взаємодії викладачів і студентів : навчально-методичний посібник. Київ : НПУ ім. М.П. Драгоманова, 2002. 114 C.

3. Голярдик Н.А. Педагогічне спілкування як фрактор взаємодії викладача і студентів у вищих навчальних закладах. Збірник наукових праць Національної академії Державної прикордонної служби України. Сер.: Педагогічні та психологічні науки. 2014. № 2. C. 64-73.

4. Діалогічна взаємодія у навчально-виховному процесі загальноосвітньої школи : книга для вчителя. Київ : ІЗМН, 1997. 136 с.
5. Кларин М.В. Инновации в мировой педагогике. Рига : НПЦ «Эксперимент», 1995. 176 с.

6. Надвинична Т.Л. Проблемно-діалогічна взаємодія викладача і студентів під час постановки та розв'язування навчальних задач. Збірник наукових праць. Серія: Педагогічні та психологічні науки / Державна прикордонна служба України, Національна академія Державної прикордонної служби України імені Б. Хмельницького. Хмельницький : Видавництво НАДПСУ. 2010. № 55. С. 209-213.

7. Надвинична Т.Л. Проблемність у контексті психологічного проєктування навчальних задач. Проблеми загальної та педагогічної психології : збірник наукових праць Інституту психології ім. Г.С. Костюка АПН України. Київ, 2008. Т. 10. Ч. 5. С. 400-408.

8. Новоженина Е.В. Становление партнерских отношений преподавателя и студентов в вузе : дисс. ... канд. пед. наук : 13.00.08. Волгоград, 2002, 221 с.

9. Подшивалкіна В.І. Соціотехнологічні аспекти профресійної діяльності спеціалістів гуманітарного профрілю. Психологія і суспільство. 2005. № 3. С. 59. Старовойтенко Н.В. До проблеми педагогічної комунікативної взаємодії викладача зі студентами в умовах навчально-виховного процесу вищого навчального закладу. Наукові записки Національного університету «Острозька академія». Серія: Психологія $i$ педагогіка. 2014. Вип. 27. С. 141-144.

10. Флоренская Т.А. Диалог в практической психологии: Наука о душе. Москва : Гуманит. Изд. Центр. ВЛАДОС, 2001. 208 с.

11. Яусс Х.Р. К проблеме диалогического понимания. Вопросы фрилософрии. 1994. № 12. С. 97-106.

12. Фурман А.В. Ідея професійного методологування : Монографрія. Тернопіль : Екон. думка, 2007. 187 с.

13. Фурман А.В. Модульно-розвивальне навчання: принципи, умови, забезпечення : монографрія. Київ : Правда Ярославичів, 1997. 340 с. 